\title{
СРПСКЕ ПАДЕЖНЕ КОНСТРУКЦИЈЕ С ПРЕДЛОГОМ НАСУПРОТ*
}

Овај рад се бави недовољно проученим српским конструкцијама с предлогом насупрот, с фокусом пажње на просторном и метафоризованом просторном значењу. Анализом је установљено да се семантичко-синтаксичка обележја која важе за једнодимензионалне, дводимензионалне и тродимензионалне материјалне односе у потпуности пресликавају и у непросторну сферу.

Кључне речи: српски језик, синтакса, спацијалност, метафоризација.

This paper deals with poorly studied Serbian case constructions with the preposition nasuprot, focusing on spatial and metaphorized spatial meaning. The analysis shows that semantical-syntactic features that apply to one-dimensional, two-dimensional, and three-dimensional material relations are fully mapped to the non-spatial domain..

Keywords: the Serbian language, syntax, spaciality, metaphorization.

1. Интересовање за конструкције с предлогом насупрот иницирано је чињеницом да им је у нашим граматикама (Стевановић 1979: 352, 379-380; Minović 1987: 123, 127, 130; Пипер, Клајн 2013: 353; Антонић 2005: 151, 192), у односу на друге предлошке структуре, посвећена несразмерно мала пажња, а штуро објашњење понекад није илустровано ниједним примером и, колико је нама познато, у србистици ${ }^{1}$ нису посебно изучаване. С намером да се основна значењска компонента детаљније образложи и прошири новим запажањима, проучаваћемо употребу овог предлога у српском језичком стандарду².

Све до појаве генеративне граматике, нарочито х-теорије (Ivić 1990: 231), предлози нису били у фокусу интересовања. Традиционални опис предлога, присутан у већини наших граматика и језичких приручника, заснован је на структуралистичком схватању да су то релационе речи редуцираног лексичког значења. Функционално усмерен приступ овим језичким јединицама ${ }^{3}$ резултирао је диференцијацијом подзначења одређених предлошких конструкција без

* Овај рад представља део истраживања у оквиру пројекта Стандардни српски језик: синтаксичка, семантичка и прагматичка истраживаға бр. 178004, који финансира Министарство просвете, науке и технолошког развоја републике Србије.

${ }^{1}$ Препозиција насупрот била је предмет контрастивне анализе хрватског и пољског језика (Daković 2018).

${ }^{2}$ Примери су ексцерпирани из електронског корпуса савременог српског језика (СрпКорп).

3 Упечатљиво је Белићево (1998: 161) објашњење њихове улоге у стварању система деклинације: , [...] од средстава језичких употребљавало се као нов диференцијални знак оно што је било могућно. То је могла бити каква реч која и сама значи односе (предлог или реч с предлошком функцијом, нпр. у енглеском језику), каква друга диференцијална реч (нпр. члан или заменица који су чували падежне разлике), или каква партикула, ма се она развила и од какве предлошке речи (то су партикуле предлошке у смислу наставка деклинације у француском језику) и сл.” 
покушаја њиховог повезивања јединственим семантичким цртама. Другачији приступ значењу, заснован на психолошким и филозофским истраживањима проблема категоризације, довео је до знатног помака и у приступу предлозима, а најизраженије у когнитивној лингвистици. Иако се пун замах локалистичке теорије код нас примећује тек у новије време (Piper 1997; Klikovac 2006; Rasulić 2004), такав приступ у србистици није новина и неке основне назнаке се уочавају већ у Даничићевој (Даничићъ 1858) обради падежа.

Међу основне премисе локалистичке теорије, на којој ће у највећој мери бити базирана анализа овог предлога, спада и становиште да језик нема само комуникативну улогу већ је и средство формализације искуства и целокупне наше спознаје (Радман 1988: 84), а да су језичке законитости ексцерпиране из општих законитости по којима функционише универзум (Piper 1997: 17). Међутим, то не значи да простор и време треба схватити кантовски, као унапред дата знања, јер се човек не рађа с готовим моделима менталних представа, већ се простор и просторне релације временом изграђују путем перцепције и кроз моторно искуство. Прве представе које дете усваја о простору засноване су на врло једноставним искуствима: одвајању, удаљености, обухватању, редоследу, и спадају у тзв. тополошки простор. Следећу фазу карактерише интернализована координаиија схема, заснована на „покушајима и погрешкама” а временом се развија и способност реверзибилног усмерења, као могућности стварања менталне представе о кретању уназад, до његовог поништавања (Piaget, Inhelder 1986).

Захваљујући томе што слику света човек моделује према свом властитом телу и његовим координацијама, свака перцепција садржи основне појмове просторне релације, а положај на којем се налази он сам као посматрач представља исходишну тачку за рашчлањивање објективне целине и свих других одредаба положаја (Kasirer 1985: 138). При том не треба занемарити ни чињеницу да субјективни доживљај објективног окружења, тј. модел психолошког простора, није идентичан стварном физичком простору. Језик се ту појављује као средство наивне слике света, као средство којим се односи у њему поједностављују. Језичко упрошћавање просторних димензија и односа спада у специфичности језика̄. Истраживања спроведена на различитим језицима показују да и поред разлике у начину на који се спацијална семантика реализује на површинском језичком плану, вреде неке универзалне законитости. На пример, експериментално је установљено да међу универзалије спада и редослед усвајања предлога којима се означавају просторни односи. Прво се усвајају предлози који се комбинују с појмовима за идентификацију тополошког простора (у и на), затим они уз појмове којима се открива представа о еуклидском тродимензионалном простору (пред, под, над), а касније и остали којима су облежени комплекснији односи (Анђелковић 2000: 175, према Parisi, Antinucci 1970).

Да је интересовање за проучавање различитих словенских предлога и предлошких конструкција у дијахроној и синхроној перспективи крајем прошлог и почетком овог века добило на значају, показује и покретање међународног пројекта посвећеног семантичко-синтаксичкој анализи предлога у словенским 
језицима, ${ }^{4}$ чији су резултати објављени 2014. и 2018. године. ${ }^{5}$ У напорима да се и српски предлози што боље сагледају и опишу, неки од њих су обрађени појединачно или у комбинацији с одређеним падежним облицима. Нису изостали ни систематични описи семантички блиских решења, како у самом српском језику тако и у контактном или контрастивном односу с неким другим језиком (Радовановић 1984-1985; Вићентић и др. 2001).

1.1. Предлог насупрот, којем је посвећена ова анализа, настао је функционалном транспозицијом прилошке у предлошку јединицу, а о условима у којима је до тога дошло обавештава нас Даничић (Даничићъ 1858: 372-375), објашњавајући да је то прилог који се изједначио с предлозима када се везао за именицу у падежном облику 6 и изгубио могућности да мења место ${ }^{7}$, при чему је задржао своју основну семантику, тако да с другим и трећим падежом значи исто, а то је: „нешто обрнуто ономе што значи реч сама". И данас се у речничкој дефиницији (РMCMX, књ. 3, 1969: 634, насупрот) прво наводи прилошко значење „супротно, противно од некога или нечега, на супротној страни", а онда упућује и на његову предлошку употребу у генитивним и дативним конструкцијама. И Стевановићево (1979: 351) тумачење овог секундарног предлога ${ }^{8}$ имплицира примарно просторну релацију „управљеност насупрот некоме или нечему”, што И. Антонић (2005: 192) развија у истом духу видећи је као „лоцираност два објекта у простору који су окренути један према другом", а Прањковић (Pranjković 2005: 246) идентификује као „фронталну локалност” при чему су посматраној конструкцији

${ }^{4}$ Ради се о пројекту Славянские предлоги в синхронии и диахронии: морфология и синтаксис, Московский государственний университет им. М.В. Ломоносова, Филологический факультет, Лаборатория общей и компьютерной лексикологии и лексикографии, 2002-2009. године.

${ }^{5}$ Всеволодова Майя Владимировна, Кукушкина Ольга Владимировна, Поликарпов Анатолий Анатольевич. Русские предлоги и средства предложного типа. Материальк к функционально-грамматическому описанию реального употребления. Книга 1. Введение в объективную грамматику и лексикографию русских предложных единии. Москва: URSS, 2014. и Всеволодова Майя Владимировна, Виноградова Екатерина Николаевна, Чаплыгина Татьяна Евгеньевна. Русские предлоги и средства предложного типа. Материальь к функияиональнограмиатическому описанию реального употребления. Книга 2. Реестр русских предложных единии $A-B$ (объективная грамматика). Москва: URSS, 2018.

${ }^{6}$ По Белићевим речима ( 1998: 92) није тешко предвидети који ће прилог уз који падеж ићи јер то зависи од његовог основног општег значења. Он напомиње да су предлошку функцију управо преузимале речи које су имале два обележја: опште зависно падежно значење и значење модификације датог падежног значења, а то су били прилози и због тога је прилошко значење претходило предлошком.

${ }^{7}$ Предлошка фраза пореклом од старих адверба карактеристична је за језике развијене синтаксичке конфигуративности, са мање-више фиксираним редом речи (SVO). Дијахроно гледано фиксирање реда речи, па и старих прилошких партикула, последица је промене активног типа језика у номинативни и развоја субјекатско-објекатских односа и синтаксичке транзитивности, а тиме и промене једнодимензионалне просторне парадигме у дводимензионалну (Павловић 2013: 130-131).

${ }^{8}$ Поред прилошког порекла речник JAZU (knj. VII, 1914: 667, nasuprot) нас обавештава и о творби препозиције насупрот у којој учествују две јединице: на-супрот. Говорећи о сложеним предлозима, Клајн (2002: 139) помиње две врсте њиховог грађења, једне настале спојем два предлога, а друге предлога и именице. Међутим, за предлог насупрот и усупрот каже да је немогуће одредити функцију другог дела. 
у хрватском језику синонимичне конструкције с предлошким изразима преко пута и визави (vis-à-vis). Из тог у основи просторног значења развио се и адверзатив као један од облика недимензионалне семантике који се приписује предлошким конструкцијама (Pranjković 2001: 25).

2. Посматрани корпус показује да поред доминантне препоноване позиције предлог насупрот може бити дистрибуиран и у постпонованом положају у односу на управну реч, нпр.:

Али зашто да ћути кад се и юен живот, веној вољи насупрот, извргава опасности; [...] самосталци су били представљени као „Бранковићи”, а њима насупрот је био Пашић, „десно крило српског господара” ког ни ћесар надмудрит не може (СрпКорп).

Та појава нарочито је изражена у примерима где је овај предлог комбинован с просентенцијално употребљеном заменицом то:

[...] и достојним презира, и који ни после бољег упознавања не би успео да побуди саосећајност. Томе насупрот, могао бих да лечим било ког дијабетичара; У том случају, поистовећујемо га са појмом законитости, то јест легалности. Томе насупрот, можемо га разумети као обједиьавајуће начело за етику која је изнад таквог правног поретка (СрпКорп).

2.1. Иначе, поред доминантних именичких, у српском језику су сасвим уобичајене заменичке конструкције с овим предлогом, а мањи број случајева у корпусу потврђује и његову комбинацију с бројем. Осим показних, међу којима су нарочито фреквентне то и ово, као и општа заменица све, којима се упућује на препоновани садржај, а целом конструкцијом врши просторна метафоризација текста (Кликовац 2008), овај предлог се комбинује и са свим личним и повратном заменицом:

Насупрот овом, циновска продукиија са звездама попут Уме Турман, Жерара Депардјеа и још двадест; Њихови су покварени, препредени и изопачени. Наши се, насупрот томе, боре витешки, трпе увреде али и праведно узвраћају; Насупрот ономе што се обично говори и пише, Свети отаи јако воли српски народ; Насупрот свему, поетичност језика не нарушава ни вечито понашање добра и зла; Hacynрот ној, Миломир Марић никад није поклањао пажюу где и како живи; Насупрот нама, наши политички противници-програме немају; Четнички покрет је насупрот себи имао снажан, млади, добро организовани и водени супарнички покрет; Cтоје један насупрот другом у мрачној собици (СрпКорп).

2.2. Насупрот припада предлозима који у пракси остварују двојаке рекцијске односе, с именским лексемама у дативу и генитиву, што потврђује и савремени корпус, у којем су забележени такви примери с готово идентичним протагонистима од којих је обично онај у фокусу пажње стациониран у (на)супротном положају према другом / од другог:

Д: [...] колико је то могуће двома људима који седе једно насупрот другом за истим столом; 
Г: [...] нису се ни погледали кад они стоје једно насупрот другог као потпуни странцฺи, обоје подједнако инхибирани и несрећни (СрпКорп).

Иако се у србистичкој литератури дативу и генитиву у овом случају углавном приписује синонимски однос, ${ }^{9}$ у делу сербокроатистичке граматичке литературе генитивни облик се сматра или секундарним или се доводи у питање његова нормативност (Daković 2018: 191). Примери обухваћени овом анализом потврђују да поред доминантне дативне конструкције у којој се бележи предлог насупрот није занемарљив ни број примера с генитивним обликом именице или заменице са значењем конкретног ентитета, и живог и неживог, у функцији просторног оријентира, или конкретних и апстрактних појмова као метафоризованих просторних оријентира, нпр.:

[...] кад они стоје једно насупрот другог као потпуни странции; [...] тетка ме је посадила у фотељу села је насупрот мене; насупрот них, на другом делу подијума, [...], орила се музика; дошли смо на обалу потока насупрот лепог врта; [...] вицекраљ нас све троје одведе под дрвеће насупрот гостионице и посадивщи нас на клупу рече; [...] насупрот феномена опипљивог света, јесте она обједињавајућа нит неколико догађаја испричаних у роману; Насупрот идеализованог лика брата и његовог, у роману непотпуно елаборираног, дионизијског схватања; [...] у македонском Уставу и законима чије усвајање инсистирају ,посредници” Перђу и Леотар, насупрот лидера ,македонског блока" Црвенковског и Георгијевског; [...] велики поборници даљег јачањ вишепартијске демократије, насупрот оних партија и појединаца који, [...] (СрпКорп).

Корпус савременог српског језика демантује мишљење о генитивном облику као архаичној категорији ${ }^{10}$, а његова употреба у различитим функционалним стиловима доводи у питање и оцену да се ради о супстандардној појави. Колебање двеју конструкција с предлогом насупрот објашњиво је у контексту посматрања промена у језику, које се одвијају поступно. Очигледно је на снази смена у перспективизацији овог типа оријентационе локализације.

Позиција објекта локализације (ОЛ), у једном случају, одмерава се одвајањем и удаљавањем од оријентира $(\mathrm{O})$ на супротну страну, што се граматикализује генитивом. Такође, када је генитив у питању не треба занемарити ни унутарјезички утицај семантички врло блиског сложеног предлога супротно од који се комбинује управо са овим падежним обликом ([...] хемијски поступак стварања неке материје спајањем, једињењем њених састојака, елемената; супротно од аланизе.).

${ }^{9}$ Да се став о употреби облика именице уз овај предлог у србистици није сасвим искристалисао, потврђују речи И. Клајна (1991: 117), који напомиње да је исправан само дативни облик и да би се као правило, где год постоји колебање између ова два облика, предност требала дати дативу, али ипак овај аутор на све то додаје да генитивни облик није у свим случајевима напоредне појаве двају падежа и погрешан.

${ }^{10}$ И. Антонић (2005: 151) констатује да је генитивни облик конструкције с предлогом насупрот некада био знатно чешћи. 
С друге стране, знатно чешћа је оријентација заснована на циљном односу, где објекат локализације заузима почетну, а оријентир у дативу крајњу тачку замишљене путање.

У том смислу може се схватити и коментар С. Павловића (2006: 324), који се пре свега односи на метафоризоване просторне односе, да се генитив реализује као последица концептуализације нежељеног дејства које се неутралише удаљавањем од аблативне тачке, а да је датив адлативно обележена позиција према којој се агенс устремљује. Дакле, посматрање оријентира као аблативно или као адлативно ангажоване позиције регулише избор једног од ових облика, а степен актуелности перспективе посматарања утиче на учеталост, односно смену њихове реализације.

3. И поред тога што је семантика овог предлога заснована на просторним релацијама, у корпусу доминирају непросторна значења, ${ }^{11}$ што се може објаснити несигурношћу у идентификацији односа који би одговарао значењу предлога насупрот, нарочито у једнодимензионалним и дводимензионалним релацијама или између појмова који означавају објекте без јасно изражених страна у тродимензионалном простору. ${ }^{12}$

Ово потврђује и анкета спроведена међу изворним говорницима српског језика ${ }^{13}$ којима је дато да међусобни положај тачака или лопти у вертикалном или хоризонталном низу идентификују избором једног или више понуђених предлога: испред, иза, изнад, испод, поред и насупрот. У зависности од перспективе посматрања сва понуђена решења могла би бити прихватљива, али се показало да предлог насупрот код испитаника који су се за њега одлучили није имао алтернативу само када су објекат локализације и оријентир сагледани као део ширег простора у којем долазе до изражаја две раздвојене, опонентне стране. На пример, распоред тачака које су део геометријског облика или су поређане у низу, тако да се добија представа двеју супротних страна, чешће је идентификован као насупротан од оних које су приказане ван било каквих оквира. Генерално, посматрани предлог углавном је био алтернативно решење и више везан за хоризонтално постављени низ, а ретко за вертикални. Било је испитаника који су се за овај предлог одлучили само једном, неки ниједном, а у тродимензионалном простору нико није идентификовао положај лопте, као објекта локализације, конструкцијом с предлогом насупрот, већ неким другим понуђеним решењем.

11 За разлику од анализе спроведене у хрватском језику на 76 примера у којима доминирају просторна значења (Daković 2018: 192), савремени српски корпус (СрпКорп) са преко 2000 примера показује сасвим другачију слику.

${ }^{12} \mathrm{C}$ обзиром на то да је језичка слика света редукована, поједностављена, човекова представа објекта локализације и локализатора углавном се своди на осну структуру основног облика тела и задржава се само основна физиономија. Управо због тога је одабрано да у анкети, која је спроведена за потребе овог истраживања, буду приказани геометријски облици који немају комплексну структуру да би разлика у односу на ту пречишћену, језичку представу, била што мања.

${ }^{13}$ Испитаници су били професори Одсека за српски језик и лингвистику и студенти мастерских студија Српског језика и књижевности. Анкета је спроведена у току 2019. године. 
Различите категорије у српском, па и у другим језицима повезане су принципом наткатегоријалне локализације, првенствено на когнитивном, а затим и на језичком плану, где су моделу категоријалне просторне ситуације коресподентни модели других непросторних значења. Будући да се на семантичку категорију простора ослањају друге непросторне категорије и да она представља прототипну локализацију (протолокализацију) (Piper 1997: 35-47), у својој анализи и ми полазимо од њених семантичко-функционалних обележја, без обзира на мању фреквентност таквих примера у корпусу.

Познато нам је да простор степенован према броју међусобно окомитих правих са једном заједничком тачком може бити једнодимензионалан, дводимензионалан и тродимензионалан.

3.1. Односи у простору који су заступљени једном правом могу се идентификовати према удаљености или међусобном положају њених сегмената. У језичкој репрезентацији таквих релација између осталог учествује и предлог насупрот као маркер двају смерова који омогућавају промену димензија у овом једнодимензионалном простору. И поред идентичности свих тачака од којих је саздана дата права, крајње тачке неке замишљене дужи чине опозитни пар, према њиховом различитом положају - почетне и крајње позиције, чија би језичка интерпретација, која укључује посматрану конструкцију, могла гласити: „почетна тачка (1) је / налази се насупрот крајњој тачки (2)". Схематски овај однос би се могао представити на следећи начин ${ }^{14}$ :

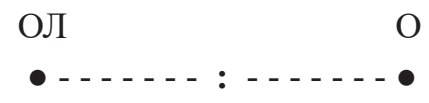

(1)

У пракси овакви случајеви су очекивани у идентификацији геометријских односа, који могу имати различиту примену, као у примерима из корпуса:

Пређен је пут између тачке А која је тачно насупрот тачки Б; [...] пада у сазвежђе Лава и то насупрот Урану (СрпКорп).

3.2. У дводимензионалном простору, који представља пројекцију физичког универзума на раван, релевантне су две димензије - дужина и ширина, а свака тачка одређена је паром координата. Предлогом насупрот спецификује се релација међу тачкама које имају једну идентичну нормалу координатне оси, тј. једнако су удаљене од хоризонталне или вертикалне осе. У пракси се такав однос може представити као „десна тачка је насупрот левој” (ОЛ1 насупрот О) и „доња тачка је насупрот горњој” (ОЛ2 је насупрот О). Схематски приказ овод односа могао би се овако приказати:

14 Положај замишљене дужи није релевантан, тј. може бити хоризонтална, вертикална или под неким углом. 

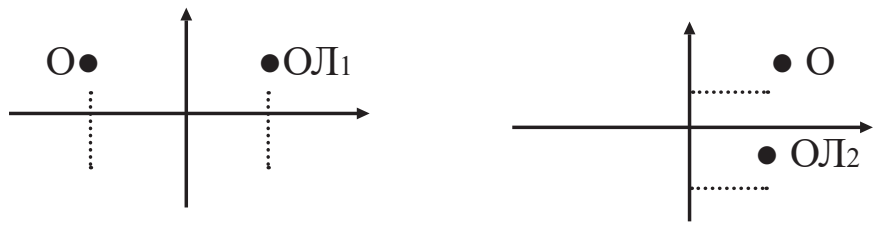

У корпусу је овај однос примењен на локализацију географских појмова (меридијана), који се формално могу представити тачкама (или низом тачака исте дужи):

То је подневак или меридијан, [...], који лежи насупрот Гриничком (почетном) подневку (СрпКорп).

3.3. Типична оријентациона локализација, како то показује већина евидентираних примера с предлогом насупрот, одвија се у тродимензионалном простору мањих или већих размера, а обухвата географске пределе, грађевинске објекте, ствари и људе. Маркираност ентитета јединственим положајем (острво), цёнтрӓлношћу (пошта), популарношћу и значајем (познато уметничко дело, вицекраљ, Богородица), личним простором говорника или саговорника (моја кућа, твој кревет) квалификује их за улогу локализатора.

Импликатура о трајном или привременом заузимању одговарајуће позиције једног ентитета у односу на други углавном је експлицирана или имплицирана глаголима типа: налазити се, сместити се, стајати, седети, нпр.:

Сама зграда Умјетничке галерије, смештена на Плочама, насупрот Локрума [...]; [...] у фоаје Медицинског иентра. Стаклена врата насупрот водила су [...];[...] на уској клупи насупрот његовом лежкају седе два човека; Затим се у комору (лежиште), које је иасупрот цеви, успе дозирана количина искључиво црног (димног) барута (СрпКорп).

За разлику од једнодимензионалног и дводимензионалног, у тродимензионалном простору релевантан је не само положај, паралелизам и раздвојеност објекта локализације и локализатора, односно оријентира, већ често и њихово усмерење - окренутост предњим странама, тј. оним странама које посматрач (приповедач) оцени као такве ${ }^{15}$ :

Испод десне (јужне) певнице, насупрот Богородичином, налази се архијерејски престо; [...] две велике Шумановићеве „Шидијанке” насупрот којих стоје велики женски актови. Обојица су ушла у крчму насупрот поштанског дома; Насупрот нашој кући стајала је једна сељачка; Прелат је седео у фотељи насупрот вицекрала; Мушкарац мирно седи на фотељи наcynpom твојој (СрпКорп).

${ }^{15}$ О улози посматрача при одређењу предње стране треба видети у Арсенијевић 2011. 
Конструкција с предлогом насупрот учествује и у идентификацији просторног односа међу живим ентитетима окренутим „лицем у лице”, а статичност објеката локализације експлицирана је глаголима такве семантике (налазити се, стајати, чучати и сл.):

Трепчини радници налазе се нон-стоп испред фабрике, насупрот наоружаним припадницима Кфора; Насупрот њима стајала је мала црногорска војска; [...] човек наоружан пушком могао је стати насупрот другом наоружаном пиштољем; [...] седе једно насупрот другом; [...] који је чучао насупрот њему (СрпКорп).

Специфичност положаја који имају објекат локализације и оријентир у примерима овога типа до изражаја долази тек сагледавањем динамичког аспекта датог сценарија. Истовремено кретање посматраних протагониста у смеру којем су окренути водило би их у сусрет један другоме, па би се у једном моменту или мимоишли или сударили. Схематски би се то могло овако приказати:

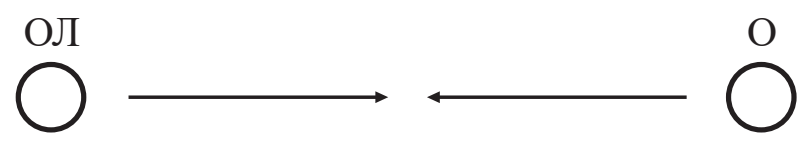

Познато је, а корпус то и потврђује, да динамичност није карактеристична за овај тип локализације, па се она у малобројним примерима везује углавном за дејство природних појава у улози оријентира (поветарац, водена струја), чије је кретање усмерено према објекту локализације. Истовремено је кретање објекта локализације усмерено према оријентиру, што резултира ефектом стварања отпора и успоравањем или онемогућавањем даљег кретања тог објекта:

За то време на гумну су младићи раж вејали, лопатама је захватали, насупрот поветариу је баиали; У документарним филмовима о природи ви ћете често видети и сторије о рибама које пливају узводно, насупрот снажнним воденим струјама (СрпКорп).

4. Већ је поменуто да просторна локализација представља протолокализацију чији се принципи функционисања пресликавају и на друге семантичке категорије. Модели синтаксичких структура и појмовно-терминолошка решења карактеристична за примарно просторни садржај примењени при опису непросторних односа спадају у домен језичке металокализације (Piper 1997: 44). Основни конститутивни спацијални елементи денотирани језиком: објекат локализащије, локализатор и оријентир пројектовани су и у непросторну сферу семантике, као и релације локациионог и оријентационог типа. Примењивост истих критерија који функционишу у свету материјалних односа при класификацији примера у којима је предлог насупрот реализован с лексиком апстрактног или конкретног али непросторног значења, показује висок степен међукатегоријалне транспозиције. Све три просторне димензије представљају базу метафоризације с примарним обележјем адверзативности. 
4.1. Уколико је природа анализираног односа подложна једнодимензионалној пројекцији, тј. уколико је сагледива као дихотомија у оквиру исте сфере, са семантичким опонентима који се раздвајају према особини, квалитету, квантитету и сл., ентитети чија се релација анализира чине антонимски пар. При томе није уочена правилност у избору опониране стране која ће бити комбинована с предлогом насупрот ${ }^{16}$ (лаж насупрот истини, илузија насупрот реалности, излазни насупрот улазни, тврд насупрот меком, стар насупрот младом, неодговорни насупрот одговорном, прогресивни насупрот конзервативном). Еквивалентна структура овој конструкцији била би конструкција с предлогом према, у односу на (лаж насупрот / према истини; илузија насупрот / у односу на реалност):

[...] иза диференцијаџије народа бивще Југославије била је дихотомија Балкан насупрот не-Балкану; Лаж насупрот истини; [...] наступа ера поларизације света на два антагонистичка табора: доминације насупрот равноправности; [...] замислимо ита је илузија насупрот реалном; Технологија није ништа друго до лажни свет, свет обмане, свет који се налази насупрот стварног света; [...] излазни податак добијен из програма по обради података. Насупрот овом податку је улазни податак; [...] (тврди диск) несавитљиви диск, најчешће неизменљив, великог капацитета и брзине. Насупрот њему је меки диск или дискета; [...] механика и физика, старе су више стотина година. Hасупрот њима су младе дисичиплине, настале пре неколико десетина година; [...] златно се истиче насупрот црној кори букава; [...] трагична и проклета смрт, насупрот добре, благе и достојанствене, вудске, смрти; [...] уживају у пространству, насупрот скученом простору тераријума; Насупрот одговорним уредницима јавних гласила, он себе назива - неодговорним уредником; [...] о суштинским разликама у виђењу државе, прогресивног насупрот конзервативном; [...] аутосугестибилно биће које у времену друштвене кризе и рата подлеже колективном, насупрот индивидуалном менталитету; [...] као оличење „капута" који стоји насупрот „гуњцу и опанку"; [...] јер се на чедности инсистирало јер стоји насупрот блуду; [...] ито изричито тврди 31 одсто испитаника, насупрот 15,5 одсто (СрпКорп).

4.2. Примери с метафоризованим просторним односима који би одговарали онима у условима дводимензионалности преузимају обележја карактеристична за те односе, па се међу појмовима чија се релација посматра уочава паралелизам, али и раздвојеност, удаљеност, баш као и међу двема тачкама исте равни на супротним странама у односу на хоризонталну или вертикалну осу. Практично, два опонентна појма, у улогама објекта локализације и оријентира, припадају дијаметрално различитим сценаријима, што се најчешће језички нотира експликацијом позитивно реализоване активности једног од њих према имплицитној негираној оног другог, нпр.: Hacynpom домаћину, гости

\footnotetext{
${ }^{16}$ Ипак, нешто се чешће с посматраним предлогом удружују појмови који би у овој врсти дихотомије могли бити оцењени као позитивни, као што је истина у односу на лаж, или реалност у односу на илузију, тврд у односу на мек итд..
} 
нису испунили очекивања [ $\longleftarrow$ домаћин је испунио очекивања, гости нису испунили очекивања]. У корелацији с овим конструкцијама могле би се појавити конструкције са сложеним предлогом за разлику од (За разлику од домаћина, гости нису испунили очекивања):

Владимир Велебит, насупрот Дедијеру, сматра да је Стаљин хтео да импресионира маршала Тита; Насупрот, сасвим насупрот Јеврејима, који су потпуно код куће и живе нормално, чисти Гриии су живели ненормално; [...] рекли да су реченичне конструкиије са да (иасупрот реченицама са како) изашле из употребе; Градови ће развијати проактиван однос насупрот пасивном чекању да подстицај дође споља; И неупућенима је јасно колико састављачи песничких, насупрот састављачима прозних антологија, имају лагоднији посао; Насупрот црти, цртицуа је, по правилу, знак спајања; Именице, као замене бројевима, имају ту предност ито се, насупрот бројевима, могу мењати по падежима; Оно ито се могло сазнати говори да пројекат промовише отворени тржишни модел, насупрот досадашњем који је ититио права стваралаца вредности; [...] насупрот млекарима, сточари изузетно задовољни откупном изеном млека од 18 динара; [...] такође инспирисана трагедијом бомбардовања, тешке емочије претапа у апстрактне слике. Насупрот вој, Николас Критофоракис представља се као реалиста, мајстор иртежа; Цео месеи је редовно ишао на све службе, али, насупрот Пекишеу, никада није хтео да пости (СрпКорп).

4.3. Пресликавање тродимензионалних просторних односа у неке друге сфере одвија се, као и у претходна два случаја, стварањем потпуно нових семантичких веза по истом принципу. Адверзативни однос метафоризацијом обухваћених појмова утемељен је на просторном распореду у којем положај и окренутост објекта локализације и оријентира претпоставља међусобно приближавање и сучељавање. Исти тип релације у непросторној сфери сагледава се као однос двеју страна ангажованих тако да се прејудицира њихова конфронтација. Осим посматране предлошке конструкције постојећа адверзативност могла би се лексикализовати глаголским прилогом исте базичне семантике, супротстављајући се, нпр.: Срески одбор у Беранама ствара се насупрот / супротстављајући се вољи представника Краљевине Југославије [Срески одбор у Беранама ствара се и тиме супротставља вољи представника Краљевине Југославије]. Илустративни су и ови примери из корпуса:

Он сам стајао је насупрот целој Академији наука, целом Универзитету, свима професорима права; У Светској организачији за интелектуалну својину, насупрот европским мишљењима, америчка администрација чврсто брани став о казненим одредбама; Његова самоћа се зато чита као симболички изазов суштини, насупрот бројним појавним маскама и привидима; [...] прићи претходном историјском искуству са новим социјалноекономским и политичким идејама, насупрот упорном истрајавању на старим идејама; значи да међу чланицама ДОС-а не постоје воља и снага стручњака који могу да подстакну реформе насупрот оним политичким странкама које желе да задрже постојеће стање; Као критичар Кашанин 
је подржавао младе песнике и сликаре насупрот традиционализму и академизму; Насупрот Михаилу Политу, Милетић одбаиује одредбе Париског уговора као негативне и штетне ${ }^{17}$ СрпКорп).

5. Сумирањем свега реченог показује се да неке чињенице везане за конструкције с предлогом насупрот досада или нису уопште помињане или нису довољно истакнуте као битне. Ипак, овом приликом бисмо још једном напоменули да се дати предлог у савременом српском језику најчешће комбинује са именицама, а по фреквентности појављивања следе заменице, и то нарочито показне, док су бројеви знатно ређи. При томе су поред доминантно препонованог положаја забележени и примери с његовом постпозицијом, нарочито у комбинацији са просентенцијализатором то, где цела конструкција учествује у просторној метафоризацији текста. Иако је употреба овог предлога у дативним конструкцијама фреквентнија и неретко се генитивне сматрају архаичнијим, а у делу стручне јавности их проглашавају и нестандардним, у савременом српском корпусу се бележе у свим фукционалним стиловима.

Доминантније по броју примера, конструкције са метафоризованим просторним значењем засноване су на односима који владају у материјалној сфери. Тако оне које би одговарале једнодимензионалном простору (тачка A je насуnрот тачки $\boldsymbol{Б}$ ) представљају пројекцију адверзативног односа као таквог без посебне спецификације, нпр. лаж насупрот истини. При пројектовању дводимензионалног просторног односа (врата су насуnрот прозору) у непросторну сферу адверзативност се испољава као тенденција удаљавања, нпр. музичари воде лагодан живот насупрот нама певачима. Просторно најкомплекснији тродимензионални односи (човек с пиштољем стајао је насупрот једном наоружсаном пушком) у непросторној сфери се препознају по својој специфичној адверзативности, која би се формално могла представити као фронтална повезаност финализована конфронтацијом, као нпр. он сам је стајао насупрот целој Академији наука, целом Универзитету, свима професорима права, где једна страна, не само да има став супротан дугој страни већ и делује у намери да оспори и елиминише другу страну, тј. активно јој се супротставља.

\section{Цитирана литература}

Антонић, Ивана. Синтакса и семантика падежа. Милка Ивић (ур.). Синтакса савременог српског језика. Проста реченица. Београд: Институт за српски језик САНУ, Београдска књига; Нови Сад: Матица српска, 2005: 119-298.

Арсенијевић, Нада. „О принципу егоцентризма у српском језику”. Граматика и лексика у словенским језицима. Срето Танасић (ур.). Нови Сад: Матица српска -

${ }^{17}$ У неким примерима као што је овај, конструкцијом с предлогом насупрот није истакнута само разлика између двеју страна, у овом случају размимоилажење у ставовима поводом одређеног друштвено-политичког догађаја, већ једна страна својим деловањем директно оспорава њој супротстављено мишљење и настоји да га потисне, па је због тога могућа и оваква интерпретација посматране предлошке конструкције. 
Београд: Институт за српски језик САНУ. 2011: 277-289.

Белић, Александар. Општа лингвистика. Изабрана дела Александра Белића. Први том. Београд: Завод за уџбенике и наставна средства, 1998.

Даничићъ, Ђуро. Србска синтакса. Део првый. Београд, 1858.

Клајн, Иван. „О склопу реченице”. Језички приручник. Београд: Радио-телевизија Београд, 1991: 117-145.

Клајн, Иван. Творба речи у савременом српском језику. Прилози граматици српског језика I. Слагање и префиксација. Београд: Завод за уџбенике и наставна средства: Институт за српски језик САНУ; Нови Сад: Матица српска, 2002.

Кликовац, Душка. „О семантици текстуалних конектора у српском језику који се састоје од предлога месних значења и поименичене заменице тај”. Зборник Матице српске за славистику 73, 2008: 177-195.

Павловић, Слободан. Детерминативни падежи у старосрпској пословноправној писмености. Нови Сад: Матица српска, 2006.

Павловић, Слободан. Узроци и механизми синтаксичких промена у српском језику, Сремски Карловци-Нови Сад: Издавачка књижарница Зорана Стојановића, 2013.

Пипер, Предраг; Иван Клајн. Нормативна граматика српског језика. Нови Сад: Матица српска, 2013.

РМC-MX. Речник српскохрватскога књижевног језика, књ. 3, Нови Сад: Матица српска, Загреб: Матица хрватска, 1969.

Стевановић, Михаило. Савремени српскохрватски језик II. (Граматички системи и књижевнојезичка норма). Београд: Научна књига, 1979.

Anđelković, Darinka. „Razumevanje imeničkih sintagmi sa prostornim značenjem na predškolskom uzrastu". Psihologija 1-2, 2000: 171-198.

Daković, Sybilla. „Hrvatski prijedlog nasuprot i njegovi poljski prijevodni ekvivalenti”. Fluminensia 30, 2018: 189-208.

Ivić, Milka. Pravci u lingvistici (2). Biblioteka XX vek. Beograd, 1990.

JAZU. Riječnik hrvatskoga ili srpskoga jezika, knj. VII, Zagreb: Jugoslavenska akademija znanosti i umjetnosti, 1914.

Kasirer, Ernst. „Jezik”. Filozofija simboličkih oblika. Novi Sad: Dnevnik - Književna zajednica Novog Sada, 1985.

Klikovac, Duška. Semantika predloga. Beograd: Filološki fakultet Univerziteta u Beogradu, 2006.

Minović, Milivoje. Sintaksa srpskohrvatskog-hrvatskosrpskog književnog jezika. Sarajevo: Svjetlost, 1987.

Parisi, D., F.Antinucci. Lexical competence.U.G.B.Flores DćArcais i W.J.M. Levelt (Eds.) Advances in Psycholliguistics, Nort-Holand Publishing Co, 1970.

Piaget, Jean, Bärbel Inhelder. Intelektualni razvoj deteta. Beograd: Zavod za udžbenike i nastavna sredstva, 1986.

Piper, Predrag. Jezik i prostor. Biblioteka XX vek. Beograd, 1997.

Pranjković, Ivo. Druga hrvatska skladnja. Sintaksičke rasprave. Zagreb: Hrvatska sveučilišna naklada, 2001.

Pranjković, Ivo, Josip Silić. Gramatika hrvatskoga jezika za gimnazije i visoka učilišta. Zagreb: Školska knjiga, 2005: 183 - 390.

Radman, Zdravko. „Ogled o percepciji”. Simbol, stvarnost i stvaralaštvo. Zagreb: Hrvatsko filološko društvo, 1988. 
Rasulić, Katarina. Jezik i prostorno iskustvo. Konceptualizacija vertikalne dimenzije u engleskom i srpskohrvatskom jeziku. Beograd: Filološki fakultet Univerziteta u Beogradu, 2004.

\section{Извор}

СрпКорп: Корпус савременог српског језика на Математичком факултету Универзитета у Београду $<$ [http://korpus.matf.bg.ac.rs.html] $>25.04 .2019$.

\section{Nada Arsenijević}

\section{SERBIAN CASE CONSTRUCTIONS WITH THE PREPOSITION NASUPROT}

\section{Summary}

The analysis of the Serbian case construction with the preposition nasuprot allowed already known facts to be supplemented and expanded with new observations. Spatial and metaphorized spatial meanings are realized by dominantly dative structures, but in all functional styles, this preposition also combines with the genitive. Adversativity, as a basic feature, is mapped from the spatial to the non-spatial domains, so it is possible to observe the metaphorization of onedimensional spatial relation, two-dimensional as more complex and three-dimensional as the most complex relation.

Keywords: the Serbian language, syntax, spaciality, metaphorization. 